\title{
Water Saving through Field Water Tubes in Transplanted Rice (Oryza sativa L.)
}

\author{
Jagruti Mahapatra*, K. Chandrasekhar, N. Venkata Lakshmi and K.L. Narasimha Rao \\ Department of Agronomy (Water Management), Advanced Post Graduate Centre, ANGRAU, \\ Lam, Guntur, India \\ *Corresponding author
}

\begin{tabular}{|l|}
\hline Ke y w o r d s \\
Rice, AWD, Field \\
water tubes, Water \\
saving
\end{tabular}

A B S T R A C T

Rice is the major staple food of the world's population which contributes a vital role in global food security. Scarcity of water resources is a major threat for the higher water requiring crops like rice and agricultural production, as a whole. Henceforth, the present field experiment was conducted to study the rice cultivation with less water under alternate wetting and drying condition and to optimize the water depth. Field water tube being a promising tool to evaluate water depth both below and above ground level has been used for the study during kharif, 2017-18 on clay soils of the Agricultural College farm, Bapatla. The experiment was laid out in Randomized Block Design with seven treatments and three replications. The treatments included seven irrigation regimes viz., continuous submergence and six treatments with alternate wetting and drying where four treatments were installed with field water tubes. The results revealed that weekly application of $3 \mathrm{~cm}$ ponded water $\left(\mathrm{T}_{3}\right)$ resulted in $47.6 \%$ water saving as compared to continuous submergence, whereas treatments imposed with field water tubes were observed with 21.6 - $28.3 \%$ less of continuous submergence. Among the four treatments with field water tubes, $5 \mathrm{~cm}$ submergence when water level receded $5 \mathrm{~cm}$ below ground level in the field water tube $\left(\mathrm{T}_{6}\right)$ was found superior in terms of yield, water saving and water saving impact.

\section{Introduction}

Rice is a major staple crop in the world as well as India. In India around 42.94 million ha is under rice cultivation with 111.0 million tonne production annually. Water requirement of Rice is higher as compared to other cereal crops and for production of $1.0 \mathrm{~kg}$ rice about 3000-5000 liters of water is required (Geethalakshmi et al., 2011). Water is a very precious resource. Due to increasing population and multifarious use in different sectors viz., agriculture, domestic and industrial, per capita availability and share of water for irrigation is declining day by day. During 2001, per capita availability of water in India was 1820 cubic meter and it is estimated that by 2025 , it is going to be declined upto 1341 cubic meter (Anonymous, 2015). Increasing competition for water has threatened agriculture for production of more water requiring crops like rice. It is expected that, by 2025, about 2 million ha of Asia's irrigated dry season rice and 13 million ha of 
irrigated wet season rice are going to be experiencing water scarcity (Tuong and Bouman, 2003). In this ongoing context of water scarcity, alternate wetting and drying (AWD) has been evolved as one of the water saving options in transplanted rice where instead of full irrigation, deficit irrigation is given by maintaining alternate cycles of saturated and unsaturated conditions. Field water tube is a practical way to implement AWD which helps in monitoring the water depth in field where irrigation water is given when a fixed depth of water recedes below the surface level after a certain number of days after disappearance of ponded water. Hence the present study was undertaken to find out optimum depth of water in field water tubes under alternate wetting and drying for increasing water productivity.

\section{Materials and Methods}

Field experiment was conducted during kharif, 2017-18 of the Agricultural college farm, Bapatla. The soil of the experimental field was clay in texture, moderately alkaline $(\mathrm{pH}-8.5)$ in reaction, low in available nitrogen, medium in available phosphorus and available potassium. The experiment was laid out in RBD with seven treatments and three replications. The treatments were : $\mathrm{T}_{1^{-}}$ Continuous submergence of $3-5 \mathrm{~cm}$ depth from transplanting to maturity, T2-Irrigation with ponded water depth of $3 \mathrm{~cm}$ at weekly interval from 15 DAT to maturity, T3Irrigation with ponded water depth of $5 \mathrm{~cm}$ at weekly interval from 15 DAT to maturity, T4AWD with $3 \mathrm{~cm}$ submergence till $5 \mathrm{~cm}$ depth of water receded below ground level in field water tubes (15 DAT to maturity), T5 - AWD with $3 \mathrm{~cm}$ submergence till $10 \mathrm{~cm}$ depth of water receded below ground level in field water tubes (15 DAT to maturity), T6 -AWD with $5 \mathrm{~cm}$ submergence till $5 \mathrm{~cm}$ depth of water receded below ground level in field water tubes (15 DAT to maturity) and T7 -
AWD with $5 \mathrm{~cm}$ submergence till $10 \mathrm{~cm}$ depth of water receded below ground level in field water tubes (15 DAT to maturity).

PVC pipe of $40 \mathrm{~cm}$ long and $15 \mathrm{~cm}$ diameter were used as field water tubes to observe the perched water level below ground surface. The bottom $20 \mathrm{~cm}$ of these tubes was perforated with small holes of $0.5 \mathrm{~cm}$ diameter at $2 \mathrm{~cm}$ apart on all sides to make the water flow in and out of the tubes. Lower half of the field water tubes with holes were inserted into the soil keeping remaining half above the ground level. While hammering the tubes, care was taken not to penetrate through the plough pan. The tube was placed in the location which was representative of the average water depth and readily accessible part of the field close to the bund. The soil from inside the tube was removed after installation so that the bottom of the tube will be visible. It was ensured that the level of water inside the tube was the same as that of water on the field at the time of installation. Water was poured inside the tubes to check that the holes were not blocked with compacted soils. The quantity of water applied in each treatment was monitored with the help of Parshall flume (Parshall, 1950) of 1 cusec capacity and throat width of $7.5 \mathrm{~cm}$. Amount of water applied (1) $=\mathrm{A} \times \mathrm{h} \times 10^{3}$, Where, $\mathrm{A}=$ Surface area of the plot $\left(\mathrm{m}^{2}\right)$ and $\mathrm{h}=$ Desired ponded water depth above the soil surface $(\mathrm{m})$. The water saving impact was determined by dividing the quantity of grain lost per hectare by the amount of water saved $\left(\mathrm{m}^{3} \mathrm{ha}^{-1}\right)$ and was expressed in $\mathrm{kg} \mathrm{m}^{-3}$. Irrigation water productivity, rain water productivity and total water productivity were estimated by using the following formulae.

Irrigation water productivity (IWP)

$\mathrm{IWP}=\mathrm{Y} / \mathrm{IWU}$

Rain water productivity (RWP)

$\mathrm{RWP}=\mathrm{Y} / \mathrm{RW}$ 
Total water productivity (TWP)

$\mathrm{TWP}=\mathrm{Y} / \mathrm{TWU}$

\section{Results and Discussion}

\section{Water use}

The experimental findings presented in Table 2 shows that there was a significant increase in amount of applied irrigation water as well as total water used (irrigation + rainfall) under continuous submergence $\left(\mathrm{T}_{1}\right)$ over other treatments. For maintaining continuous submergence throughout the crop growth period, alternate day irrigations were given which resulted in increased water use under $\mathrm{T}_{1}$. $\mathrm{T}_{5}$ was found to be the second most water consuming treatment after $\mathrm{T}_{1}$; however, there was no significant difference among the four AWD treatments irrigated through field water tubes $\left(\mathrm{T}_{4}, \mathrm{~T}_{5}, \mathrm{~T}_{6}\right.$ and $\left.\mathrm{T}_{7}\right)$.

Amount of water applied was significantly lower under $T_{2}$ which was on a par with that of $T_{3}$. The results are in accordance with the findings of Banerjee et al., (2008), Mote et al., (2017) and Sathish et al., (2017).

Treatment with $5 \mathrm{~cm}$ submergence after $10 \mathrm{~cm}$ depletion of water BGL $\left(\mathrm{T}_{7}\right)$ was found to be superior over other treatments in effective utilization of rainfall, whereas continuous submergence $\left(T_{1}\right)$ recorded the least amount of effective rainfall. Similar results were also observed by Pandey et al., (2010).

\section{Water productivity assessment}

Results of the experiment presented in Table 2 shows that irrigation water productivity was found significantly higher under $T_{2}$ than other treatments which was due to utilization of the least amount of water among all treatments. It was followed by $\mathrm{T}_{3}$; whereas, continuous submergence $\left(T_{1}\right)$ was found with significantly lower IWP over all other treatments. Santheepan and Ramanathan (2016) also found similar results in their experiment. Similarly, total water productivity was recorded highest under $T_{2}$ and it was found to be superior over other treatments. $T_{1}$ recorded significantly lower TWP than all other treatments except $T_{5}$ and $T_{7}$. This result was in accordance with Sathish et al., (2017). Among all treatments, a significant increase in rain water productivity was observed under continuous submergence. $T_{6}$ was found to be the next best treatment which was on a par with $\mathrm{T}_{5}$; whereas the least RWP was recorded under $\mathrm{T}_{7}$ over other irrigation treatments; however, the difference between $\mathrm{T}_{7}$ and $\mathrm{T}_{2}$ were not significant. Similar findings were also given by Kima et al., (2014).

\section{Water saving and water saving impact}

Water saving under different deficit irrigation treatments ranged from $21.59 \%$ to $47.62 \%$ as compared to the conventional method i.e. continuous submergence of $5 \mathrm{~cm}$ throughout the crop growth period (Table 3 ).

Ponded water depth of $3 \mathrm{~cm}$ at weekly interval $\left(T_{2}\right)$ was observed with the highest amount of water saving $(62.05 \mathrm{~cm})$ whereas $T_{5}$ recorded $28.13 \mathrm{~cm}$ less water used than that of $\mathrm{T}_{1}$.

Water saving impact is the amount of grain lost per unit amount of water saved. It ranged from 0.16 to $0.32 \mathrm{~kg} \mathrm{~m}^{-3}$. Water saving impact of the treatment $T_{6}$ was found to be the lowest which implies that with every $\mathrm{m}^{3}$ of water saving, the grain production loss was only $0.16 \mathrm{~kg}$ whereas $\mathrm{T}_{7}$ registered the highest value which means that more amount of grain loss $(0.32 \mathrm{~kg})$ was caused with each unit quantity of water saved.

This could be due to the fact that all the water needs under this treatment was met through rainfall $(22.68 \mathrm{~cm})$ that has caused to receive less quantity of irrigation water. 
Table.1 Number of productive tiller $\mathrm{m}^{-2}$, grain yield and economics of transplanted rice as influenced by irrigation schedules

\begin{tabular}{|c|c|c|c|}
\hline Treatments & $\begin{array}{c}\text { Number of } \\
\text { productive tiller } \mathbf{~ m}^{-2}\end{array}$ & $\begin{array}{c}\text { Grain yield } \\
\left(\mathrm{kg} \mathrm{ha}^{-1}\right)\end{array}$ & B:C ratio \\
\hline $\mathrm{T}_{1}$ & 288.2 & 5573 & 1.79 \\
\hline $\mathrm{T}_{2}$ & 236.5 & 4348 & 1.54 \\
\hline $\mathrm{T}_{3}$ & 244.2 & 4453 & 1.58 \\
\hline $\mathrm{T}_{4}$ & 266.4 & 4674 & 1.57 \\
\hline $\mathrm{T}_{5}$ & 270.2 & 4910 & 1.66 \\
\hline $\mathrm{T}_{6}$ & 273.3 & 5092 & 1.75 \\
\hline $\mathrm{T}_{7}$ & 262.2 & 4664 & 1.61 \\
\hline $\mathrm{SEm}$ & 14.00 & 113.40 & - \\
\hline $\mathrm{CD}(\mathbf{p = 0 . 0 5 )}$ & 29.6 & 349.5 & - \\
\hline
\end{tabular}

Table. 2 Water used and water productivity of transplanted rice as influenced by Irrigation schedules

\begin{tabular}{|c|c|c|c|c|c|c|}
\hline Treatments & $\begin{array}{c}\text { IWU } \\
(\mathrm{cm})\end{array}$ & $\begin{array}{c}\mathbf{R W U} \\
(\mathrm{cm})\end{array}$ & $\begin{array}{c}\text { TWU } \\
(\mathrm{cm})\end{array}$ & $\begin{array}{c}\text { IWP } \\
\left(\mathrm{kg} \mathrm{m}^{-3}\right)\end{array}$ & $\begin{array}{c}\text { RWP } \\
\left(\mathrm{kg} \mathrm{m}^{-3}\right)\end{array}$ & $\begin{array}{c}\text { TWP } \\
\left(\mathrm{kg} \mathrm{m}^{-3}\right)\end{array}$ \\
\hline $\mathrm{T}_{1}$ & 116.2 & 14.1 & 130.3 & 0.49 & 3.97 & 0.43 \\
\hline $\mathrm{T}_{2}$ & 49.9 & 18.3 & 68.3 & 0.87 & 2.38 & 0.64 \\
\hline $\mathrm{T}_{3}$ & 62.9 & 15.9 & 78.8 & 0.71 & 2.82 & 0.57 \\
\hline $\mathrm{T}_{4}$ & 75.5 & 17.9 & 93.4 & 0.62 & 2.61 & 0.50 \\
\hline $\mathrm{T}_{5}$ & 86.8 & 15.4 & 102.2 & 0.57 & 3.19 & 0.48 \\
\hline $\mathrm{T}_{6}$ & 80.4 & 15.9 & 96.4 & 0.64 & 3.20 & 0.53 \\
\hline $\mathrm{T}_{7}$ & 75.1 & 22.7 & 97.8 & 0.62 & 2.06 & 0.48 \\
\hline $\mathrm{SEm}$ & 4.44 & 0.42 & 4.55 & 0.02 & 0.11 & 0.02 \\
\hline $\mathrm{CD}(\mathrm{p}=\mathbf{0 . 0 5})$ & 13.7 & 1.3 & 14.0 & 0.1 & 0.3 & 0.1 \\
\hline
\end{tabular}

Table.3 Water saving and water saving impact under deficit irrigation as compared to Continuous submergence

\begin{tabular}{|c|c|c|c|}
\hline Treatments & $\begin{array}{c}\text { Water saving } \\
(\mathrm{cm})\end{array}$ & $\begin{array}{c}\text { Water saving } \\
(\%)\end{array}$ & $\begin{array}{c}\text { Water saving } \\
\text { impact }\left(\mathrm{kg} \mathrm{m}^{-3}\right)\end{array}$ \\
\hline $\mathrm{T}_{2}$ & 62.1 & 47.6 & 0.21 \\
\hline $\mathrm{T}_{3}$ & 51.5 & 39.5 & 0.22 \\
\hline $\mathrm{T}_{4}$ & 36.9 & 28.3 & 0.29 \\
\hline $\mathrm{T}_{5}$ & 28.1 & 21.6 & 0.31 \\
\hline $\mathrm{T}_{6}$ & 33.9 & 26.0 & 0.16 \\
\hline $\mathrm{T}_{7}$ & 32.5 & 24.9 & 0.32 \\
\hline
\end{tabular}




\section{Economics}

The highest B: C ratio of 1.79 was realized under continuous submergence in spite of more cost of cultivation because of the highest yield registered under this treatment (Table 1). It was closely followed by $5 \mathrm{~cm}$ submergence when $5 \mathrm{~cm}$ water dropped BGL in field water tube $\left(\mathrm{T}_{6}\right)$ with $\mathrm{B}$ : $\mathrm{C}$ ratio of 1.75. The lowest $\mathrm{B}: \mathrm{C}$ ratio (1.54) recorded with $\mathrm{T}_{2}$ which might be due to less net returns as compared to the other treatments. Michael and Simon (2017) also reported that total cost of production and gross returns were higher under continuous flooding as compared to the AWD treatment.

Field water tube was found as an effective tool or water control device in transplanted rice through which water level below and above the ground level can be observed and proper water depth can be maintained. Continuous submergence performed better in increasing growth and yield of transplanted rice; on the other hand, AWD irrigations with field water tubes found superior over irrigations with 3 to $5 \mathrm{~cm}$ ponded water at weekly interval. However, considering water saving and water productivity under water deficit conditions, AWD irrigations with field water tubes was found suitable without considerable reduction in yield, especially $\mathrm{T}_{6}$ (5 $\mathrm{cm}$ submergence when $5 \mathrm{~cm}$ drop below ground level) with higher total water productivity $\left(0.53 \mathrm{~kg} \mathrm{~m}^{-3}\right)$, irrigation water productivity $\left(0.64 \mathrm{~kg} \mathrm{~m}^{-3}\right)$ and BCR (1.75).

\section{References}

Anonymous. 2015. Population growth and per capita water availability in India. httpsl://www.indiastat.com/table/percapita-availability-data/24/watersupply/18198/365176/data.aspx. Last seen on $24 / 10 / 2018$
Banerjee, P., Dutta, D., Bandyopadhyay, P and Maity, D. 2008. Production potential, water use efficiency and economics of hybrid rice under different levels of irrigation and weed management practices. Oryza, 45 (1): 30-35.

Geethalakshmi, V., Ramesh, T., Palamuthirsolai, A and Lakshmanan, A. 2011. Agronomic evaluation of rice cultivation systems for water and grain productivity. Archives of Agronomy and Soil Science. 57 (2): 159-166.

Indiastat.com.2017-18, https://www.indiastat.com/table/agricult ure/2/rice/17194/1096352/data.aspx

Kima, A. S., Chung, W. G and Wang Y. M. 2014. Improving irrigated low land rice water use efficiency under saturated soil culture for adoption in tropical climate conditions. Water. 6: 2830-2846.

Michael, M.U and Simon, S.R. 2017. Performance of green super rice 5 genotype under different water management schemes. International Journal of Current Microbiology and Aapplied Sciences. 6 (3): 769-777.

Mote, K., Praveen Rao, V., Ramulu, V., Avil Kumar, K and Uma Devi. M. 2017. Standardization of alternate wetting and drying (AWD) method of water management in low land rice (Oryza sativa L.). International Journal of Plant Production. 11 (4): 516-532.

Pandey, N., Verma, A. K and Tripathi, R. S. 2010. Response of hybrid rice to scheduling of nitrogen and irrigation during dry season. Oryza, 47 (1): 34-37.

Parshall, R.L. 1950. Measuring water in irrigation channels with parshall flumes and small weirs. USDA, Circular No. 843.

Santheepan, S and Ramanathan, SP. 2016. Investigation on AWDI method with field water tube for rice production under SRI. International Journal of 
Agricultural Science and Research. 6 (3): 117-124.

Sathish, A., Avil Kumar, K., Raghu Rami Reddy, P and Uma Devi, M. 2017. Effect of different crop establishment methods and irrigation regimes on rice (Oryza sativa L.) yield and water use efficiency. Internal Journal of Current
Microbiology and Applied Sciencce, 6(9): 90-95.

Tuong T.P and Bouman, B.A.M. 2003. Rice production in water scarce environments. In: Proceedings of the water productivity workshop, International Water Management Institute, Colombo, Sri Lanka, November 12-14, 2001.

\section{How to cite this article:}

Jagruti Mahapatra, K. Chandrasekhar, N. Venkata Lakshmi and Narasimha Rao, K.L. 2018. Water Saving through Field Water Tubes in Transplanted Rice (Oryza sativa L.). Int.J.Curr.Microbiol.App.Sci. 7(11): 2119-2124. doi: https://doi.org/10.20546/ijcmas.2018.711.237 